\title{
Characteristics of Cucumber mosaic virus isolated from Zea mays in Korea
}

\author{
Mi-Kyeong Kim¹, Hae-Ryun Kwak', Su-Heon Lee', Jeong-Soo Kim¹, Kook-Hyung Kim², ByeongJin Cha ${ }^{3 *}$ \\ and Hong-Soo Choi ${ }^{*}$ \\ ${ }^{1}$ Crop Protection Division, National Academy of Agricultural Science, Suwon 441-707, Korea \\ ${ }^{2}$ Department of Agricultural Biotechnology and Plant Genomics and Breeding Institute, Seoul National University, Seoul 151- \\ 921, Korea \\ ${ }^{3}$ Department of Plant Medicine, Chungbuk National University, Cheongju 361-763, Korea
}

(Received on July 6, 2011; Revised on August 6, 2011; Accepted on August 10, 2011)

A virus causing mottle and stunt symptom on Zea mays was observed around Ulleng-do, Korea and identified as Cucumber mosaic virus (CMV-ZM) based upon biological, serological, and molecular characteristics. In host range studies, the $\mathrm{CMV}-\mathrm{ZM}$ isolate produced local lesions on Datura stramonium, Vigna unguiculata, Cucurbita moschata, Chenopodium amaranticolor, Ch. quinoa, whereas this isolate produced systemic mosaic on Nicotiana tabacum cv. 'Xanthi-nc', Capsicum annuum, Solanum lycopersicum, Solanum melongena, Cucurbita pepo, and $Z$. mays. In addition, chlorotic local rings on inoculated leaves along with severe mosaic, malformation, and fern leaf symptoms on upper systemic leaves were shown in $N$. glutinosa plants. Complete nucleotide sequences of each genomic RNA segment was determined and compared to those of the other CMV strains. Comparison of the nucleotide sequence of 1a open reading frame (ORF) revealed approximately 89.292.4\% sequence identity with each CMV subgroup IA and IB strain, while showing only $78 \%$ sequence identity with CMV subgroup II. Nucleotide sequence analysis of RNA2 ORFs revealed 85.3-97.6\% sequence identity with subgroup I. In ORFs of RNA3, levels of nucleotide sequence identities were higher than 9299.2\% with CMV subgroup I and lower than $82 \%$ with CMV isolates of subgroup II. These results suggest that CMV-ZM isolate is more closely related to subgroup I than subgroup II and therefore, $\mathrm{CMV}-\mathrm{ZM}$ isolate might be classified into as CMV subgroup I based on biological and molecular analysis.

Keywords : Cucumber mosaic virus, subgroup I, Zea mays

\footnotetext{
*Co-corresponding authors.

HS Choi

Phone) +82-31-290-0431, FAX) +82-31-290-0434

E-mail) hschoi@rda.go.kr

BJ Cha

Phone) +82-43-261-2557, Fax) +82-43-271-4414

E-mail)bjcha@chungbuk.ac.kr
}

Cucumber mosaic virus (CMV) is the type species of the genus Cucumovirus in the family Bromoviridae (Palukaitis and Garcia-Arenal, 2003). CMV has the broadest host range of among known plant viruses, infecting more than 1,200 species of plants from monocotyledons to dicotyledons (Douine et al., 1979; Kaper and Waterworth, 1981). Various kinds of symptoms are produced by CMV on different hosts (Choi et al., 2004; Jeon et al., 2006; Kaper and Waterworth, 1981; Lee et al., 2007; Lee et al., 2008; Martelli and Russo, 1985; Oh et al., 2008). CMV is efficiently transmitted by more than 75 species of aphids including Myzus persicae and Aphis gossypii in a styletborne, nonpersistent manner (Palukaitis et al., 1992). The genome of CMV is a single-stranded, positive-sense RNA having three RNA segments, which contain five genes encoding proteins designated $1 \mathrm{a}, 2 \mathrm{a}, 2 \mathrm{~b}, 3 \mathrm{a}$, and capsid protein (CP) (Ding et al., 1994; Palukaitis and GarciaArenal, 2003; Palukaitis et al., 1992). The numerous strains of CMV have been classified into two major groups by nucleotide sequence similarity, and subgroup I has been further divided into two subgroups by phylogenetic analyses (Aramburu et al., 2007; Chaumpluk et al., 1996; Roossinck et al., 2003).

Maize (Zea mays), family Gramineae, is widely cultivated throughout the world producing 817 million tonnes worldwide in 2009 which was more than rice or wheat (FAO, 2009). Virus disease incidences on maize were reported in all countries where maize crops were grown and the natural occurrences of more than 40 distinct viruses in maize crops including Barley stripe mosaic virus (BSMV), Barley yellow dwarf virus (BYDV), Cucumber mosaic virus (CMV), Maize chlorotic dwarf virus (MCDV), Maize dwarf mosaic virus (MDMV), Maize leaf fleck virus (MLFV), Rice black-streaked dwarf virus (RBSDV), and Rice stripe virus (RSV) were reported in the world (Damsteegt et al., 1981; Shurtleff et al., 1986; White, 1999). Some of these viruses cause occasionally serious economic damage in maize production. CMV infection on maize was first identified in 1934 in Florida and thus maize was 
reported as its natural host (Wellman, 1934). In addition, natural occurrence of maize infection with CMV in Europe has been reported only in former Yugoslavia (Panjan, 1966).

In Korea, three viruses including Cucumber mosaic virus (Lee et al., 1982), Maize dwarf mosaic virus (Lee et al., 1981), and Rice black streaked dwarf virus (Jeong et al., 1987; Lee et al., 1978; Lee et al., 2005) have been reported on maize plants. Although CMV infection does not cause significant damage in maize production, it should not be overlooked since this virus has wide host range. In this paper, we analyzed the biological characteristics, obtained complete genome sequence, and conducted phylogenetic relationship of CMV-ZM isolate with the other CMV strains and/or isolates.

Maize plants showing irregular mosaic stripe, mottle on the leaves and stunt on the stem (Fig. 1) were collected from Uleng-island in 2006. The collected isolates identified by electron microscopy and RT-PCR using CMV specific primers (Forward; 5'-TGGTCGTCCAACTATTAACCAC3', Reverse; 5'-TACTGATAAACCAGTACCGGTGA-3'). Quick dip preparation was used for the observation of virus particle from field collected samples. Virus particles were not observed under electron microscope (EM, LEO 912AB; Carl Zeiss, Germany) at $100 \mathrm{kV}$. General spherical viruses including CMV are difficult to observe under EM because of low concentration and similarity to the other organelles in plant cell. Virus isolate was inoculated onto Chenopodium quinoa and representative single lesion on inoculated plant was used as inoculum for three consecutive transfers. The single lesion from the third inoculation was then inoculated onto Nicotiana tabacum cv. 'Xanthinc' for virus propagation. Purified virus preparations stained with $0.5 \%$ uranyl acetate revealed the presence of typical isometric particles of 28-30 nm diameter (data not

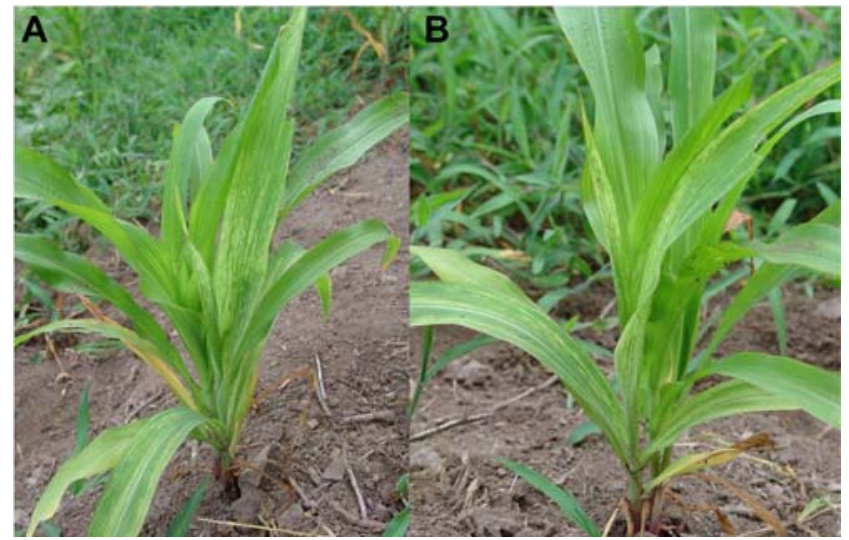

Fig. 1. Viral disease symptoms on maize plants in the field (A), and CMV-infected maize plants showing mottle and stunt (B) on leaves. shown).

Virus was purified from the inoculated Nicotiana tabacum cv. 'Xanthi-nc' as described previously (Palukaitis et al., 1992) and the purified CMV isolate, named as CMV-ZM isolate, was subjected to biological and molecular analyses. For symptom evaluation, the CMV-ZM was mechanically inoculated onto 14 different plant species belonging to Solanaceae, Leguminosae, Chenopodiaceae, Brassicaceae, Cucurbitaceae, and Gramineae. Symptoms caused by CMVZM on tested plants were compared with those caused by CMV-Z and -RB (Kim et al., 2010a, 2010b). Symptom appearance induced by the CMV-ZM along with CMV-Z and CMV-RB were observed from at least 10 plants per tested species collected from three independent experiments. Inoculated plants were maintained in an insect-free greenhouse at $20-25^{\circ} \mathrm{C}$. Symptoms were observed for $3-4$

Table 1. Symptoms developed on indicator plants that were mechanically inoculated with Cucumber mosaic virus isolate ZM (CMV-ZM)

\begin{tabular}{|c|c|c|c|}
\hline \multirow{2}{*}{ Indicator plants } & \multicolumn{3}{|c|}{$\begin{array}{l}\text { Symptoms a on the leaves } \\
\text { (inoculated/upper) }\end{array}$} \\
\hline & CMV-ZM & CMV-Z & CMV-RB \\
\hline \multicolumn{4}{|l|}{ Solanaceae } \\
\hline $\begin{array}{l}\text { Nicotiana tabacum cv. } \\
\text { 'Xanthi-nc' }\end{array}$ & $\mathrm{cl} / \mathrm{vc}, \mathrm{m}$ & $\mathrm{cl} / \mathrm{m}$ & $\mathrm{cl} / \mathrm{m}$ \\
\hline N. glutinosa & $\mathrm{crl} / \mathrm{sm}, \mathrm{f}$ & $\mathrm{cl} / \mathrm{m}$ & $-/ \mathrm{m}$ \\
\hline Capsicum anпuиm & $\mathrm{cl} / \mathrm{cl}, \mathrm{m}$ & $-/ \mathrm{m}$ & $-/ \mathrm{vc}$ \\
\hline Solanum lycopersicum & $-/ \mathrm{m}$ & $-/ \mathrm{m}, \mathrm{mal}$ & $-/ \mathrm{m}$ \\
\hline Datura stramonium & $\mathrm{cl} /-$ & $\mathrm{crl} /-$ & $\mathrm{cl} /-$ \\
\hline Solanum melongena & $-/ \mathrm{m}$ & $\mathrm{cl} / \mathrm{m}$ & $\mathrm{cl} / \mathrm{vc}, \mathrm{m}$ \\
\hline \multicolumn{4}{|l|}{ Leguminosae } \\
\hline Vigna unguiculata & $\mathrm{pp} /-$ & $\mathrm{nl} /-$ & $\mathrm{pp} /-$ \\
\hline Phaseolus angularis & $-1-$ & $-/ \mathrm{m}$ & $-/ \mathrm{m}$ \\
\hline \multicolumn{4}{|l|}{ Cucurbitaceae } \\
\hline $\begin{array}{l}\text { Cucurbita pepo } \\
\text { 'Taeyang' }\end{array}$ & $\mathrm{cl} / \mathrm{cl}, \mathrm{st}$ & $\mathrm{cl} / \mathrm{sm}, \mathrm{st}$ & $\mathrm{cl} / \mathrm{sm}, \mathrm{mal}$ \\
\hline $\begin{array}{l}\text { Cu. moschata } \\
\text { 'Jinhan Aihobag' }\end{array}$ & $\mathrm{cl} /-$ & $\mathrm{cl} / \mathrm{vc}$ & $-1-$ \\
\hline \multicolumn{4}{|l|}{ Brassicaceae } \\
\hline Brassica pekinensis L. & $-1-$ & $-1-$ & $-1-$ \\
\hline Raphanus sativus L. & $-1-$ & $-1-$ & $-1-$ \\
\hline \multicolumn{4}{|l|}{ Chenopodiaceae } \\
\hline $\begin{array}{l}\text { Chenopodium. } \\
\text { amaranticolor }\end{array}$ & $\mathrm{nl} /-$ & $\mathrm{nl} /-$ & $\mathrm{nl} /-$ \\
\hline Ch. quinoa & $\mathrm{nl} /-$ & $\mathrm{nl} /-$ & $\mathrm{pp} /-$ \\
\hline
\end{tabular}

${ }^{\mathrm{a}} \mathrm{cl}$, chlorotic local; $\mathrm{nl}$, necrotic local; crl, chlorotic ring local; pp, pin point; vc, vein clearing; m, mosaic; sm, severe mosaic; f, fern leaves; st, stunt; mal, malformation; -, no symptom.

${ }^{\mathrm{b}}$ CMV-Z, Cucumber mosaic virus - Zucchini (Kim et al., 2010b)

${ }^{\circ}$ CMV-RB, Cucumber mosaic virus - Rudbeckia bicolor (Kim et al., 2010a) 
weeks post inoculation. CMV infection was confirmed by symptom appearance and by enzyme linked immunosorbent assay (ELISA) using ELISA test kits purchased from Agdia (USA; Hsu et al., 2000). Absorbance at 405nm was measured with a model microplate Reader (EL312e EIA; Bio-Tek, USA).

CMV induces a variety of symptoms depending on the host plant species and on the virus strain. Host range and symptoms on tested plants by CMV-ZM were summarized in Table 1. CMV-ZM caused systemic infection in $N$. tabacum cv. 'Xanthi-nc', N. glutinosa, Capsicum annuum, Solanum esculentum, Solanum melongena, Cucurbita pepo and local infection in Datura stramonium, Vigna unguiculata, Cu. moschata, Chenopodium amaranticolor, and Ch. quinoa (Fig. 2). However, CMV-ZM isolate failed to infect and induce symptoms in Brassica campestris, Raphanus sativus, and Phaseolus angularis. The experimental host range of CMV-ZM was similar to that reported for CMV-Fny isolate (Palukaitis et al., 1992). The host range and symptoms of CMV-ZM differ in some respect from previous reported CMV-Z and -RB isolates (Kim et al., 2010a, 2010b). Comparing symptoms of those CMV isolates, CMV-ZM induced chlorotic local ring on inoculated leaves of $N$. glutinosa. However, systemic symptoms were similar to those caused by the other two isolates. The necrotic ringspot symptom on inoculated leaves has been reported in CMV lily isolates (CMV-Ly2 and-Ly8) on $N$. tabacum cv. 'Xanthi-nc', but necrotic ringspot symptom on upper non-inoculated leaves was only observed from CMVLy8 (Lee et al., 2007). CMV-Z, -RB, and CMV-ZM also differed significantly in their pathogenicity on $P$. angularis, $C u$. moschata (Green pumpkin), and Z. mays. CMV-ZM did not induce systemic symptoms on Phaseolus angularis whereas systemically symptoms were observed from CMV-

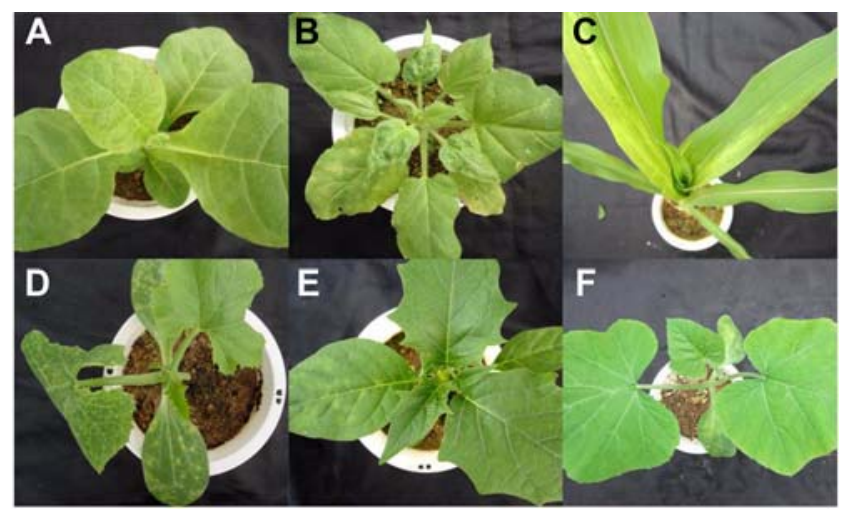

Fig. 2. CMV-ZM induced chlorotic local lesions in inoculated leaves and systemic spotting or mosaic in Nicotiana tabacum cv. Xanthi-nc (A), N. glutinosa (B), Zea mays (C), and Cucurbita pepo (D) whereas only chlorotic local lesions were formed Datura stramonium (E) and Cucurbita moschata (F).
$\mathrm{Z}$ and -RB infected leaves. CMV-ZM and -RB do not cause a systemic infection in $\mathrm{Cu}$. moschata. On the other hand, $\mathrm{CMV}-\mathrm{Z}$ isolate was obtained from $\mathrm{Cu}$. pepo, which showed vein clearing symptom on upper non-inoculated leaves. Interestingly, only CMV-ZM isolate caused systemic infection causing mottle, yellowing stripe, stunt on $Z$. mays leaves (Table 2; Fig. 2). However, CMV-Z and -RB isolates did not induce a systemic infection on upper leaves in $Z$. mays. Although some CMV isolates can infect Z. mays plant (Douine et al., 1979; Wahyuni et al., 1992; Ryu et al., 1998), natural CMV infection on $Z$. mays was rarely observed. Altogether, these three tested CMV isolates showed clear differences in host reaction of specific plant species. CMV-ZM isolate induce systemic symptoms in $Z$. mays but did not cause systemic symptoms in $P$. angularis. Thus, these differences are considered as unique characteristics of CMV-ZM.

The total RNAs were extracted using the total RNA kit (iNtRON, Korea) from leaves of purified virus preparation. To amplify complete genomic regions, a two-step Reverse Transcription-Polymerase Chain Reaction (RT-PCR) protocol was used. The first strand cDNA was synthesized with AMV reverse transcriptase (Promega, USA) and subjected to thermocycling amplification using LA Taq DNA polymerase (TaKaRa, Japan). The primers were designed to sequence full length genome of each segments based on the previously reported CMV sequences available in GenBank of NCBI (Kim et al., 2010a, 2010b). The PCR products were purified using PCR gel/direct extraction kit (iNtRON, Korea) and cloned into pGEM-T easy vector (Promega, USA) according to the manufacturer's instructions followed by transformation into Escherichia coli JM109. Complete nucleotide sequences of each genomic RNA segment were determined and submitted to GenBank (accession no. JN180309, JN180310, JN180311). The sequences were then compared to equivalent sequences from a range of other CMV isolates gene present in GenBank. Multiple nucleotide sequence alignments were performed by using Clustal W (Geneious pro 5.13). Assembled nucleotide sequences and the deduced amino acid sequences were

Table 2. Comparative analysis of infectivity of CMV isolates in maize

\begin{tabular}{ccc}
\hline \hline \multirow{2}{*}{ CMV isolates } & \multicolumn{2}{c}{ Symptoms $^{\mathrm{a}}$ on the leaves } \\
\cline { 2 - 3 } & Inoculated & Upper \\
\hline CMV-Z & $\mathrm{cl}(7 / 12)$ & $-(0 / 12)$ \\
CMV-RB & $\mathrm{cl}(9 / 12)$ & $-(0 / 12)$ \\
CMV-ZM & $\mathrm{cl}(12 / 12)$ & mo,yst, st $(12 / 12)$ \\
\hline
\end{tabular}

${ }^{a} \mathrm{cl}$, chlorotic local; mo, mottle; yst, yellowing stripe; st, stunt; -, no symptom. 
Table 3. Nucleotide/amino acid sequence identities (\%) between CMV-ZM and the previously reported strains of CMV

\begin{tabular}{|c|c|c|c|c|c|c|}
\hline \multirow{3}{*}{ Isolate } & \multirow{3}{*}{ Strains $^{\mathrm{a}}$} & \multicolumn{5}{|c|}{ Nucleotide and amino acid identity (\%) } \\
\hline & & \multirow{2}{*}{$\frac{\text { RNA1 }}{1 \mathrm{a}}$} & \multicolumn{2}{|c|}{ RNA2 } & \multicolumn{2}{|c|}{ RNA3 } \\
\hline & & & $2 \mathrm{a}$ & $2 b$ & $3 a$ & $\mathrm{Cp}$ \\
\hline \multirow{15}{*}{ CMV-ZM } & CMV-Fny & $91.7 / 97.8$ & $96.8 / 97.5$ & $97.3 / 97.3$ & $97.6 / 99.3$ & $99.2 / 100$ \\
\hline & CMV-Mf & $92.4 / 97.1$ & $96.6 / 97.2$ & $96.1 / 97.3$ & $97.5 / 99.3$ & $98.0 / 99.5$ \\
\hline & CMV-Leg & $91.8 / 97.0$ & $96.2 / 96.8$ & $93.1 / 85.5$ & $98.0 / 99.6$ & $97.7 / 98.2$ \\
\hline & CMV-Tfn & $91.3 / 97.4$ & $92.1 / 93.6$ & $87.9 / 81.7$ & 93.9/96.8 & $95.4 / 99.1$ \\
\hline & CMV-Y & $91.2 / 96.1$ & 97.0/97.9 & $97.6 / 96.4$ & 97.9/99.6 & $97.6 / 97.2$ \\
\hline & CMV-Z & $92.3 / 98.0$ & $96.3 / 96.8$ & $96.4 / 95.5$ & $96.2 / 99.3$ & $97.0 / 98.6$ \\
\hline & CMV-RB & $92.5 / 96.0$ & $96.3 / 96.8$ & $97.3 / 98.2$ & $97.0 / 99.3$ & $98.6 / 99.5$ \\
\hline & CMV-NT9 & $91.5 / 97.5$ & $92.1 / 93.8$ & $87.9 / 81.7$ & $93.7 / 96.8$ & $95.1 / 98.6$ \\
\hline & CMV-Ix & $90.8 / 96.5$ & $90.7 / 92.6$ & $86.7 / 80.0$ & $92.0 / 94.3$ & $92.7 / 95.9$ \\
\hline & CMV-IA & $89.2 / 94.4$ & $90.6 / 91.8$ & $85.3 / 74.5$ & $92.5 / 96.1$ & $92.5 / 97.7$ \\
\hline & CMV-CTL & $90.8 / 95.8$ & $91.5 / 94.4$ & $88.0 / 82.7$ & $94.1 / 96.0$ & $93.0 / 97.7$ \\
\hline & CMV-Ls & $78.2 / 85.5$ & $73.1 / 76.6$ & $64.7 / 53.5$ & $78.9 / 83.2$ & $76.9 / 82.0$ \\
\hline & CMV-Ly & $78.1 / 85.0$ & $73.2 / 76.0$ & $64.4 / 52.5$ & $78.7 / 83.5$ & $76.6 / 82.5$ \\
\hline & CMV-Trk7 & $78.2 / 85.3$ & $73.1 / 76.3$ & $65.3 / 53.5$ & $78.6 / 83.9$ & $76.1 / 80.6$ \\
\hline & CMV-Q & $78.2 / 84.9$ & $73.1 / 75.1$ & $64.0 / 53.5$ & $79.1 / 83.2$ & $77.2 / 82.9$ \\
\hline
\end{tabular}

${ }^{\mathrm{a}}$ The Genbank accession number of the reference CMV isolates: ZM(JN180309, JN180310, JN180311); Fny (D00356, D00355, D10538); Mf (AJ276479, AJ276480, AJ276481); Leg(D16403, D16406, D16405); Tfn (Y16924, Y16925, Y19626); Y (D12537, D12538, D12499); Z (GU327366, GU327367, GU327368); RB (GU327363, GU327364, GU327365); NT9 (D28778, D28779, D28780); Ix (Y20220, U20218, U20219); IA (AB042292, AB042293, AB042294); CTL (EF213023, EF213024, EF213025); Ls (F416899, AF416900, AF127976); Ly (AF198101, AF198102, AF198103); Trk7 (AJ007933, AJ007934, L15336); Q (X02733, X00985, M21464). Standard subgroup I isolates are Fny, Mf, Leg, Tfn, Y, NT9, Ix, IA and CTL. Standard subgroup II CMV isolates are Ls, Ly, Trk7 and Q.

analyzed using the software package Mega 5.0, DNAMan 4.02, and Geneious pro 5.13. Phylogenetic analyses were performed employing Maximum likehood method that is packaged in the MEGA 5.0 software (Nei et al., 2000).

Comparative sequence analysis disclosed that the $1 \mathrm{a}, 2 \mathrm{a}$, 2b, 3a, and CP ORFs of CMV-ZM had 89.2-92.5\%, 90.6$97 \%, 85.3-97.6 \%, 92-98 \%$, and $92.5-99.2 \%$ sequence identity, respectively, with CMV subgroup I isolates at the nucleotide level (Table 3). In contrast, identities of 64 to $79.1 \%$ were observed with subgroup II isolates at the nucleotide level. Amino acid sequences analysis of five ORFs of CMV-ZM and subgroup I isolates showed about 74.5-100\% sequence identity. In CMV-ZM, 1a ORF showed highest sequence identity at nucleotide level with the CMV-Mf isolate (92.4\%) and two ORFs of RNA2 showed 97 and $97.6 \%$ sequence identity with the CMV-Y isolate. The $3 \mathrm{a}$ and CP ORFs showed sequences identity of 98 and 99.2\%, with the CMV-Leg and -Fny isolates, respectively. Nucleotide and amino acid sequences of five ORF genes of CMV infecting Zea mays showed greatest identity with CMV subgroup I isolates.

The phylogenetic tree was divided into two large groups (subgroup I and II) based on nucleotide sequences of RNAs 1, 2 and 3 (Fig. 3). In addition, the RNA2 and 3 was clearly subdivided into two subgroups IA and IB, however, these further divergences were not obvious in phylogenetic analysis of RNA1. CMV-ZM isolate was more closely clustered with CMV-RB isolate of subgroup I in the RNA1. Analysis of RNA2 and 3 revealed mono-phyletic clustering with subgroup IA. The homology of the ORF was over $95 \%$ in subgroup IA isolates except 1a gene. CMV subgroup I is subdivided further into IA and IB on the basis of gene sequences and phylogenetic relationships (Palukaitis and Zaitlin 1997; Roossinck 2002). CMV-ZM showed more than $90 \%$ sequences identity at the nucleotide level with subgroup IB.

Relationship of three CMV isolates was compared using pathogenicity to host plants and multiple alignment analyses of the five ORFs (1a, 2a, 2b, 3a, and CP; data not shown). The amino acid sequence analysis of CMV-Z and -RB with CMV-ZM showed higher than 95.5\% sequence identity. Several amino acid variations were found in 1a gene. Amino acids sequence alignment of 1 a gene between CMV-ZM, CMV-Z, and -RB showed 2 differences from position 468 (Ala to Val) and 900 (Ser to Ala). For 2a protein sequences, these three isolates had two unique variations, the $3^{\text {th }}$ Phe to Ser and the $804^{\text {th }}$ Ala to Thr. In this regard, it is worth mentioning that the amino acid variations on 2a of RNA2 were reported to be responsible for causing systemic symptoms on maize (Rao et al., 1982). The 

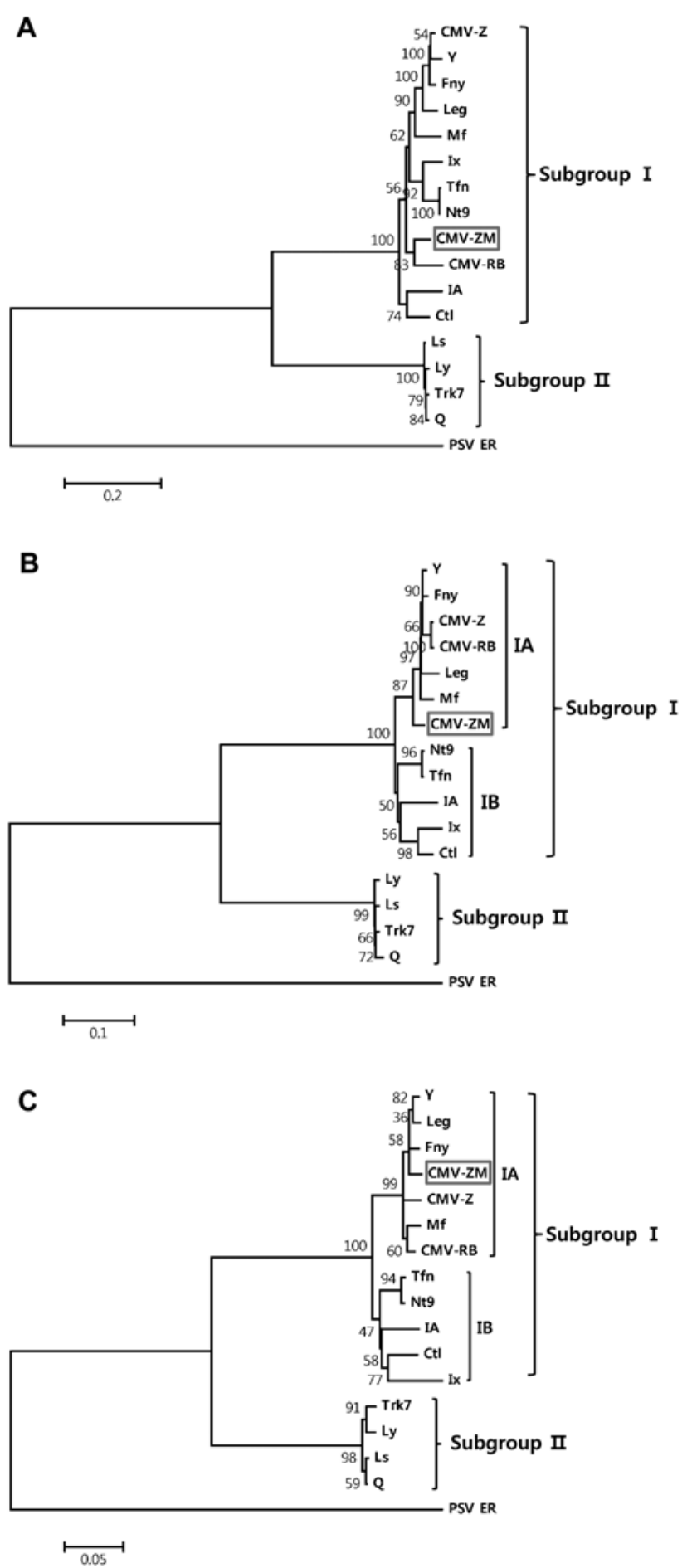

Fig. 3. Maximum likehood method phylogenetic trees base on MEGA 5.0 software derived from nucleotide sequences of the RNA segments 1, 2 and 3 of CMV-ZM with previously reported CMV isolates (panels $\mathrm{A}, \mathrm{B}$, and $\mathrm{C}$, respectively). Peanut stunt virus (PSV) was used as an outgroup.

variations of amino acids were not observed in $2 \mathrm{~b}, 3 \mathrm{a}$, and $\mathrm{CP}$ genes (data not shown). The sequence(s) and/or genes in RNA3 have been reported to be related in resistance breaking in maize (Marchoux et al. 1975; Ryu et al., 1998). However, we could not find corresponding amino acid sequence variations in RNA3. These results suggest that the other region and/or genes of CMV are also involved in pathgenicity and thus indicating that complex variations are involved in the pathogenicity of CMV.

Although CMV has one of the widest host ranges among all plant viruses, including a great number of dicotyledonous plants, only a few monocotyledonous plants are reported as hosts. The sudden occurrence of CMV in monocotyledonous may be associated with the widespread occurrence of aphids since the abundance of the birdcherry oat aphid (Rhopalosiphum padi) increased in maize in Korea (Lee et al., 1992; Yoon et al., 1974). Results of this study indicated that the virus isolate causing stripe, mottle and stunt symptoms on maize was identified as CMV-ZM belonging to subgroup I based upon biological and molecular analyses. This is the first reported sequence of an isolate of CMV naturally occurring in maize. Further molecular characterization by constructing and analyzing infectious clones will be required for identification of sequences and/or genes involved in pathogeniciy.

\section{Acknowledgements}

This study was carried out with the support of "Cooperative Research Program for Agricultural Science \& Technology Development (Project No. PJ006952)”, Rural Development Administration, Republic of Korea.

\section{References}

Aramburu, J., Galipienso, L. and Lopez, C. 2007. Reappearance of Cucumber mosaic virus isolates belonging to subgroup IB in tomato plants in north eastern Spain. J. Phytopathol. 155:513-518.

Chaumpluk, P., Sasaki, Y., Nakajima, N., Nagano, H., Nakamura, I., Suzuki, K., Mise, K., Inouye, N., Okuno, T. and Furusawa, I. 1996. Six new subgroup I members of Japanese Cucumber mosaic virus as determined by nucleotide sequence analysis on RNA3's cDNAs. Ann. Phytopathol. Soc. Jpn. 62:40-44.

Cho, J. D., Lee, S. H., Kim, J. S., Choi, G. S., Kim, H. R., Chung, B. N. and Ryu, K. H. 2006. Characteristics of Cucumber mosaic virus -VCH causing vein chlorosis on red pepper in Korea. Res. Plant Dis. 12:226-230.

Choi, G. S., Kim, J. H., Kim, J. S. and Choi, J. K. 2004. Characterization of Cucumber mosaic virus isolated from Water chickweed (Stellaria aquatica). Plant Pathol. J. 20:131-134.

Damsteegt, V. D. 1981. Exotic virus and viruslike diseases of maize. pp 110-123 in virus and virus-like diseases of maize in the United States, edited by Gordon D. T., J. K. Knoke, and G.E. Scott. Ohio Agricultural Research and Development 
Center; Southern Cooperative Series Bulletin 247, Wooster, USA.

Ding, S. W., Anderson, B. J., Haase, H. R. and Symons, R. H. 1994. New overlapping gene encoded by the Cucumber mosaic virus genome. Virology. 198:593-601.

Douine, L., Quiot J. B., Marchoux, G. and Archange, P. 1979. Recensement des especes vegatales sensible au virus de la mosaique du concombre (CMV). Etude bibliographique. Annales de Phytopathologie 11:439-475.

Food and Agriculture Organization of the United Nations, Statistics Division 2009. Maize, rice and wheat: area harvested, production quantity, yield.

Jeon, Y. W., Hong, J. S., Lee, S. Y., Ryu, K. H. and Choi, J. K. 2006. Characterization of an isolate of Cucumber mosaic virus isolated from Canna generalis Bailey. Res. Plant Dis. 12:298302.

Hsu, H. T., Barzuna, L., Hsu, Y. H., Bliss, W. and Perry, K. Y. 2000. Identification and subgrouping of Cucumber mosaic virus with mouse monoclonal antibodies. Phytopathology. 90:615-620.

Kaper, J. M. and Waterworth, H. E. 1981. Cucumoviruses. Handbook of Plant Virus Infections and Comparative Diagnosis. 258-332.

Kim, M. K., Kwak, H. R., Ko, S. J., Lee, S. H., Kim, J. S., Kim, K. H., Cha, B. J. and Choi, H. S. 2010a. Chatacteristics of Cucumber mosaic virus infecting pin wood coneflower in Korea. Plant Pathol. J. 26:93-98.

Kim, M. K., Kwak, H. R., Jeong, S. G., Ko, S. J., Lee, S. H., Kim, J. S., Kim, K. H., Choi, J. K., Choi, H. S. and Cha, B. J. 2010 b. First report of Cucumber mosaic virus infecting from Zucchini in Korean. Plant Pathol. J. 26:139-148.

Lee, B. C., Hong, Y. K., Hong, S. J., Park, S. T. and Lee, K. W. 2005. Occurrence and detection of Rice black-streaked dwarf virus in Korea. Plant Pathol. J. 21:172-173.

Lee, J. A., Choi, S. K., Yoon, J. Y., Hong, J. S., Ryu, K. H., Lee, S. Y. and Choi, J. K. 2007. Variation in the pathogenicity of lily isolates of Cucumber mosaic virus. Plant Pathol. J. 23:251259.

Lee, H. G., Kim, S. R., Jeon, Y. W., Kwon, S. B., Ryu, K. H. and Choi, K. J. 2008. Identification and characterization of three isolates of Cucumber mosaic virus isolated from weed hosts. Res. Plant Dis. 14:15-20.

Lee, W. K. and Seo, H. Y. 1992. On eighteen aphids (Tribe aphidini) occurring in Korea with description of a new species (Homoptera: aphididae). Kor. J. Entomol. 22:101-111.

Martelli, G. P. and Russo, M. 1985. Virus-host relationships.
Symptomatological and ultrastructural aspects. In The Plant Viruses. Polyhedral Virions with Tripartite Genomes, pp. 163205. Edited by R.I.B. Francki. New York: Plenum Press

Marchoux, G., Marrou, J., Devergne, J. C., Quiot, J. B., Douine, L. and Lot, H. 1975. Cucumber mosaic virus hybrids constructed by exchanging RNA components. Meded. Fac. Landbouwwet. Rijksuniv. Gent. 40:59-72.

Nei, M. and S. Kumar. 2000. Molecular evolution and phylogenetics. Oxford University Press, New York. pp. 333.

Oh, S. M., Kim, S. R., Hong, J. S., Ryu, K. H., Lee, G. P. and Choi, J. K. 2008. Characterization of an isolate of Cucumber mosaic virus isolated from Chinese aster (Callistephus chinensis). Res. Plant Dis. 14:229-232.

Palukaitis, P., Roossinck, M. J., Dietzgen, R. G. and Francki, R. I. 1992. Cucumber mosaic virus. Adv. Virus Res. 41:281-348.

Palukaitis, P. and Garcia-Arenal, F. 2003. Cucumoviruses. Adv. Virus Res. 62:241-323.

Panjan, M. 1966. About some manifestations of mosaic on corn in Yugoslavia. Rev. Roum. Biol. Botanique 11:159-162.

Rao, A. L. N. and Francki, R. I. B. 1982. Distribution of determinants for symptom production and host range on the three RNA components of Cucumber mosaic virus. J. Gen. Virol. 61:197-205.

Ryu, K. H., Kim, C. H. and Palukaitis, P. 1998. The coat protein of Cucumber mosaic virus is a host range determinant for infection of Maize. Mol. Plant-Microbe Interact. 11:351-357.

Roossinck, M. J. 2002: Evolutionary history of Cucumber mosaic virus as deduced by phylogenetic analyses. J. Virol. 76:33823387.

Roossinck, M. J. 2003. Plant RNA virus evolution. Curr. Opin. Microbiol. 6:406-409.

Shurtleff, M. C. 1986. Compendium of corn diseases, 2nd edition, St. Paul, Minnesota: Am. Phytopathol. Soc. 105.

Wahyuni, W. S., Dietzgen, R. G., Hanada, K. and Francki, R. I. B. 1992. Serological and biological variation between and within subgroup I and II strains of Cucumber mosaic virus. Plant Pathol. 41:28-297.

Wellman, F. L. 1934. Infection of Zea mays and various Gramineae by celery mosaic virus in Florida. Phytopathology, 24:1035-1037.

White, D. G. 1999. Compendium of corn diseases, 3rd edition, St. Paul, Minnesota: Am. Phytopathol. Soc. 38-43

Yoon, S. K. and Choi, S. S. 1974. A list of aphids found on growing crops. College of agricultural science, Wonkwang Univ. 5:69-74. 